\title{
COMPARATIVE ANALYSIS OF THE STRATEGIC OBJECTIVES OF \\ EUROPEAN UNION FOR THE PAST PROGRAMMING PERIOD 2007-2013 AND FOR THE CURRENT PROGRAMMING PERIOD 2014-2020
}

\author{
Miroslav Raicov, Andrea Feher, Tabita Adamov, Sorin Stanciu \\ Banat's University of Agricultural Sciences and Veterinary Medicine "King Michael I of \\ Romania" from Timisoara Faculty of Farm Management \\ 119 Calea Aradului Street, 300645 Timisoara, Romania \\ mikiraicov@gmail.com
}

\begin{abstract}
The growing competition between different regions, thus their activities performed under both within and outside the European Union represents a fact of the "globalized" world in which we are living.

For many years, the regional disparities in terms of development level and life quality were subject to national policies of the Member States. Many improvements have been observed since the European Union initiated the policy of reducing them.

The Cohesion Policy of the European Union has an unique irreplaceable role in the coagulation of integrated development strategies, comprising interventions in different areas, such as infrastructure, research and innovation, employment, education, business, environment protection, climate changes and energy efficiency within a package of coherent policies addressing to regional or even local context, being one of the most visible policies, especially in what regards the relationship with citizens. Thus, the Cohesion Policy target is represented by supporting the process of reducing the disparities between the regions and Member States more developed of the European Union and the ones that are less developed.
\end{abstract}

Keywords: Cohesion Policy, strategic objectives, programming period

\section{INTRODUCTION}

The enlargement of the European Union had led at increasing the gaps of economic development between old and new Member States, whose level of development is much lower. With the entry into the European Union (EU) of the new members, the Gross Domestic Product (GDP) environment/capita of the EU decreased by $12.5 \%$. Also, one in four regions at NUTS II level of the European Union has a GDP/capita of less than 75\% of the Community average. Beyond the GDP statistics, there are still complex inequalities between Member States and the other regions, due to differences regarding the followings:

- infrastructure;

- quality of the environment;

- unemployment and workforce skills relevant to development;

- size and diversity of business;

- level of innovation and the use of technology in business.

In order to recover the wasted years in a system that thought differently the economy, freedom and development, and to assert within the European Union of a healthy nation, prosperous, educated, free and dignified, the European integration of Romania should be seen as a process to contribute to economic development, to participate with performance and competitiveness on the internal market of European Union. Within the current conditions, where the Romanian economy is still facing structural problems serious enough, we need coherent and unitary strategies aiming at scheduling, prioritizing and pursuing national development policies. 


\section{MATERIAL AND METHOD}

The methods used were analysis, synthesis, comparison method, deduction and induction. The materials and data used were taken from the Ministry of European Funds, and from various national and international publications, on which we made own interpretations.

\section{RESULTS AND DISCUSSION}

The Cohesion Policy has its primary legal basis in the text of EU Treaty (Title XVII "Economic and Social Cohesion" and Art. 148 on the European Social Fund) (CATANĂ, 2007). The aim to strengthen economic and social cohesion is mentioned explicitly in the Article 2 of the Treaty of Amsterdam, being a valued objective of the European Union. More specifically, Article 158 mentions cohesion as a precondition for the harmonious development of the EU, stating the will of "reducing disparities between the levels of development of the various regions and the backwardness of the least favored regions or islands, including rural areas".

Following the evaluations of policies implemented at European level during the period 2000-2006 and given the objectives of the Lisbon Strategy for the programming period 2007-2013 there were established three objectives of the Cohesion Policy:

- "Convergence" Objective, for the regions with a GDP/capita below 75\% of the EU average (the entire territory of Romania was placed under this objective);

- "Regional Competitiveness and Employment" Objective;

- "European Territorial Cooperation" Objective.

For the period 2007-2013, the Cohesion Policy of EU has been reformed to better meet the objectives set in Lisbon and Gothenburg (economy based on knowledge, research and technological development, sustainable development, employment). Following this reform, the Cohesion Policy has had three tools:

- European Regional Development Fund;

- European Social Fund;

- Cohesion Fund.

The three instruments were designed to help at reducing economic development disparities between the different parts of Europe, with emphasis on knowledge and innovation, creating jobs, cooperation between regions and their transformation into attractive places to invest and work (FEHER, 2009).

The Cohesion Policy in its new form, has three objectives: Convergence (supporting regions lagging behind in terms of economic development), Regional Competitiveness and Employment (supporting regions other than those lagging behind as development level, to achieve the Lisbon Agenda targets) and European Territorial Cooperation (promoting a balanced development of the entire Community territory by encouraging cooperation and exchange of best practices between all EU regions).

\section{- "Convergence" Objective}

"Convergence" Objective was aimed at improving conditions for economic growth and for the factors contributing to a real convergence for the Member States and least developed regions.

In the European Union of 27 Member States (year 2007), this objective was referring to 84 regions situated in 17 Member States, ie 154 million people whose GDP per capita is 
below $75 \%$ of the Community average. In a system of progressive suspension of aid ("phasing out"), this target has also included other 16 regions which numbered 16.4 million inhabitants having a GDP that had slightly exceeding the threshold as a result of statistical effect of European Union enlargement.

The amounts allocated to the objective amounted to 282.8 billion euros, representing $81.5 \%$ of the total amount distributed as follows:

- 199.3 billion euros for the regions covered by the "Convergence" Objective;

- 14 billion for the regions that are at the stage of gradual suspension of aid;

- 69.5 billion euro for the Cohesion Fund, which applies to 15 Member States.

- "Regional Competitiveness and Employment" Objective

"Regional Competitiveness and Employment" Objective was intended to strengthen the competitiveness and attractiveness of regions and the employability of the workforce through a dual approach. This consists of the followings:

- the introduction of development programs to help regions to anticipate and to be

friendly to economic changes stimulating innovation, knowledge society, entrepreneurship and environmental protection and improving accessibility;

- increasing the number and quality of jobs by adapting the workforce.

\section{- "European Territorial Cooperation" Objective}

"European Territorial Cooperation" Objective was organized along three axes: cross-border cooperation, transnational cooperation and inter-regional cooperation.

This objective was designed to strengthen cross-border cooperation due to some local and regional initiatives performed jointly, to strengthen transnational cooperation through actions to promote integrated territorial development and to boost interregional cooperation, as well as exchange of experience. Over 181 million people (representing $37.5 \%$ of the total European Union population) live in cross border areas. All regions and all citizens of the Union belong to one of the 13 transnational cooperation area. The 8.7 billion euro $(2.5 \%$ of the total budget dedicated to this objective) were distributed as follows:

- 6.44 billion euros for cross-border cooperation;

- 1.58 billion euros for transnational cooperation;

- 445 million euros for interregional cooperation.

The maximum co-financing coefficients for each goal were:

- Convergence: between $75 \%$ and $85 \%$;

- Competitiveness and Employment: between 50\% and 85\%;

- European Territorial Cooperation: between $75 \%$ and $85 \%$;

- Cohesion Fund: 85\%.

Romania was eligible under two objectives: Convergence and European Territorial Cooperation.

The Cohesion Policy of the European Union for the period 2014-2020 aims to achieve the strategic objectives of the EU regarding "smart growth, sustainable and inclusive favorable", formulated in the document "Europe 2020- A European strategy for smart, sustainable and inclusive growth "(EUROPEAN COMMISSION, 2010).

Adopted in the year 2010, the strategy generically entitled "Europe 2020" includes the common objectives to the Member States in the view of a smart, sustainable and inclusive growth. Although launched at a time of economic crisis, the aim of the strategy was to contribute at improving the competitive position of the European Union at the horizon of 
the year 2020, maintaining the model of social market economy in parallel with the efficiency of resources use.

This strategic document includes three priorities mutually reinforced, namely:

- smart growth: developing an economy based on knowledge and innovation;

- sustainable growth: promoting a more efficient economy in terms of resources use, more biological and more competitive;

- inclusive favorable growth: promoting an economy with a high rate of employment, ensuring social and territorial cohesion (Figure 1).

\section{Smart growth}

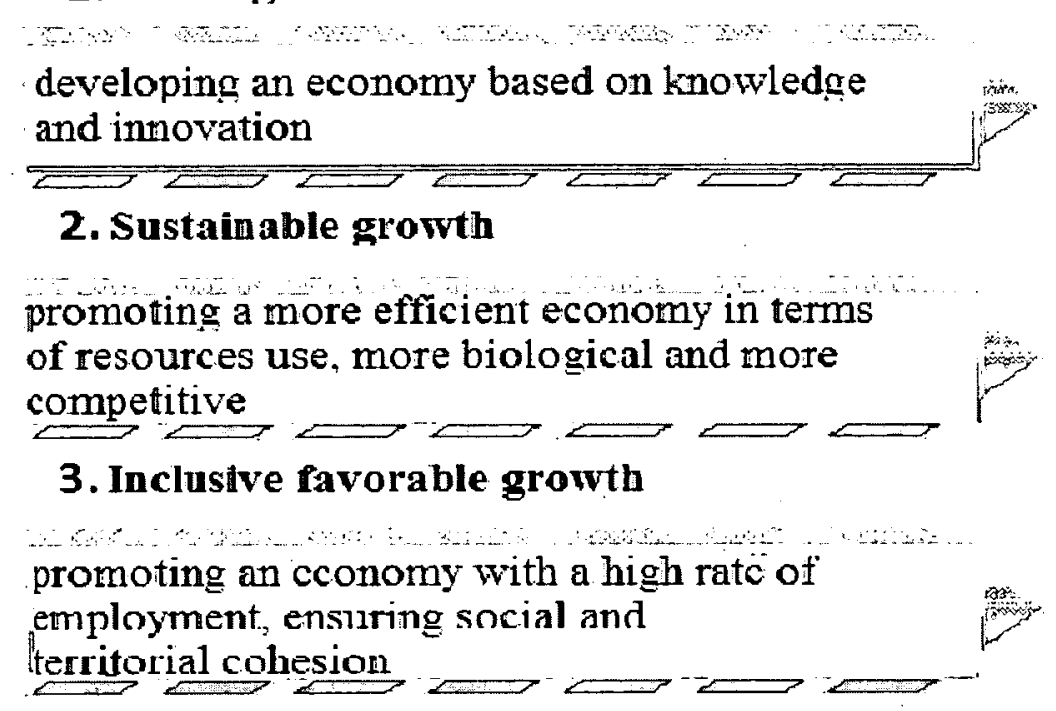

Figure 1. EU strategic objectives for the period 2014-2020

In line with these priorities there were established the following objectives to be achieved by the year 2020 within the European Union:

- $75 \%$ of the population aged between 20 and 64 to have a job;

- $3 \%$ of EU GDP to be invested in research- development (R-D);

- the "20/20/20" objectives in what regards climate/ energy must be met (including an emission reduction increased to $30 \%$ if there are favorable conditions in this direction);

- the share of early school leavers to be reduced below $10 \%$ level and at least $40 \%$ of the younger generation to have a tertiary degree;

- the number of people at risk of poverty to be reduced by 20 million.

The objectives set are representative for the strategic priorities of the period 2014-2020 but are not exhaustive, in the meaning that for their achievement is necessary to undertake a wide range of actions at national level, at the European Union and internationally (GoșA et al., 2014).

To ensure that each Member State tailors the Europe 2020 Strategy to its particular situation, the Commission has proposed that these EU objectives to be translated into national targets and trajectories. In what follows, we summarized the objectives to be reached at EU level and Romania at the horizon of the year 2020 (Table 1): 
Table 1. The objectives of Europe 2020 Strategy

\begin{tabular}{|c|c|c|c|}
\hline 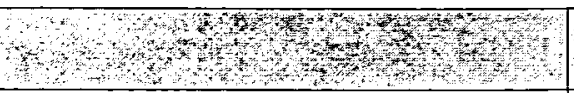 & Targets of EU & Targets of Romania & $\begin{array}{l}\text { Current situation } \\
\text { in Romania }\end{array}$ \\
\hline The employment rate $(\%)$ & $75 \%$ & $70 \%$ & $63,8 \%$ \\
\hline $\begin{array}{l}\text { The share of Research- Development in } \\
\text { GDP }\end{array}$ & $3 \%$ & $2 \%$ & $0,48 \%$ \\
\hline Targets for reducing $\mathrm{CO}_{2}$ emissions & $\begin{array}{l}-20 \% \text { (compared to } \\
\text { the level of } 1990)\end{array}$ & $\begin{array}{l}-19 \% \text { (compared to } \\
\text { the level of } 1990)\end{array}$ & $51,84 \%$ \\
\hline Renewable energy & $20 \%$ & $25 \%$ & $22,90 \%$ \\
\hline $\begin{array}{l}\text { Energy efficiency, reducing energy } \\
\text { consumption in Mtoe }\end{array}$ & $\begin{array}{c}368 \text { Mtoe (20\% } \\
\text { increase in energy } \\
\text { efficiency) }\end{array}$ & $\begin{array}{c}10 \text { Mtoe }(19 \% \\
\text { increase in energy } \\
\text { efficiency) }\end{array}$ & 7,3 Mtoe $(16 \%)$ \\
\hline Early school leaving in \% & $10 \%$ & $11,3 \%$ & $17,4 \%$ \\
\hline Tertiary education in $\%$ & $40 \%$ & $26,7 \%$ & $21,8 \%$ \\
\hline $\begin{array}{l}\text { Reduction of population at risk of } \\
\text { poverty or social exclusion (number) }\end{array}$ & 20 million & 580000 & 240000 \\
\hline
\end{tabular}

Source: EC Europe 2020 targets; Partnership agreement of Romania for the programming period 2014-2020

In order to contribute to the European Union strategy for smart, sustainable and inclusive growth there were formulated the following thematic objectives:

1. Strengthening research, technological development and innovation;

2. Improving the access and use, as well increasing the quality of ICT;

3. Improving the competitiveness of SMEs, the agricultural sector (for the EAFRD) and the fisheries and aquaculture sector (for the EMFF);

4. Supporting the shift towards an economy of low- carbon dioxide emissions in all sectors;

5. Promoting climate change adaptation, risk prevention and management;

6. Preserving and protecting the environment and promoting resources efficiency use;

7. Promoting sustainable transport systems and removing bottlenecks from the key network infrastructures;

8. Promoting sustainability and quality of jobs and supporting workforce mobility;

9. Promoting social inclusion, combating poverty and of all forms of discrimination;

10. Investments in education, training and vocational training for skills and lifelong learning;

11. Strengthening the institutional capacity of public authorities and stakeholders and of an efficient public administration (REGULATION (EU) No. 1303, 2013).

For Romania to achieve the objectives of the Europe 2020 strategy, our country should meet the following challenges (MINISTRY OF EUROPEAN FUNDS, 2014):

\section{Competitiveness and local development}

II. People and Society

III. Infrastructure

IV. Resources

V. Administration and Governance.

For each challenge in terms of development there were selected thematic objectives to contribute at their support, as follows (Table 2): 
Review.on Agriculture and Rural Development 2016 vol. 5 (1-2) ISSN 2063-4803

Table 2. Correspondence of the thematic objectives and the development challenges from Romania

\begin{tabular}{|c|c|}
\hline $\begin{array}{c}\text { Challenge in terms of } \\
\text { development }\end{array}$ & Thematic Objective \\
\hline \multirow{3}{*}{ COMPETITIVENESS } & 1. Strengthening research, technological development and innovation \\
\hline & 2. Improving access and use and increasing the quality of ICT \\
\hline & $\begin{array}{l}\text { 3. Improving the competitiveness of SMEs, of the agricultural sector (for the } \\
\text { EAFRD) and of fisheries and aquaculture sector (for the EMFF) }\end{array}$ \\
\hline \multirow{5}{*}{$\begin{array}{l}\text { PEOPLE AND } \\
\text { SOCIETY }\end{array}$} & 2. Improving access and use and increasing the quality of ICT \\
\hline & 8. Promoting sustainability and quality of jobs and supporting workforce mobility \\
\hline & 9. Promoting social inclusion, combating poverty and all forms of discrimination \\
\hline & 10. Investments in education, training and vocational training for skills \\
\hline & $\begin{array}{l}\text { 11. Strengthening the institutional capacity of public authorities and stakeholders } \\
\text { and of an efficient public administration }\end{array}$ \\
\hline \multirow{3}{*}{ INFRASTRUCTURE } & 2. Improving access and use and increasing the quality of ICT \\
\hline & $\begin{array}{l}\text { 7. Promoting sustainable transport systems and removing bottlenecks from the } \\
\text { key network infrastructures }\end{array}$ \\
\hline & 9. Promoting social inclusion, combating poverty and all forms of discrimination \\
\hline \multirow{5}{*}{ RESOURCES } & 4. Supporting the shift towards an economy of low- carbon dioxide emissions \\
\hline & 5. Promoting climate change adaptation, risk prevention and management \\
\hline & $\begin{array}{l}\text { 6. Preserving and protecting the environment and promoting resources efficiency } \\
\text { use }\end{array}$ \\
\hline & $\begin{array}{l}\text { 7. Promoting sustainable transport systems and removing bottlenecks from the } \\
\text { key network infrastructures }\end{array}$ \\
\hline & 9. Promoting social inclusion, combating poverty and all forms of discrimination \\
\hline \multirow[b]{2}{*}{ GOVERNANCE } & 2. Improving access and use and increasing the quality of ICT \\
\hline & $\begin{array}{l}\text { 11. Strengthening the institutional capacity of public authorities and stakeholders } \\
\text { and of an efficient public administration }\end{array}$ \\
\hline
\end{tabular}

Source: MFE Partnership Agreement of Romania for the 2014-2020 programming period

For the current programming period, Romania has been allocated a total of about 23 billion euros from the Cohesion Policy funds (10\% more than during the period 2007-2013).

\section{CONCLUSIONS}

The European Union as a whole represents a key economic power globally but there can still be found large disparities between Member States, which is a major structural weakness. In this regard, the European Union has adopted a policy of economic and social cohesion aimed at achieving economic development harmonious and balanced of these, in particular by promoting the reduction of disparities in terms of development between different regions/ countries of the European Union, of the equal opportunities and sustainable development.

The regional policy has already proved its significant added value in spreading growth and prosperity across the whole Union and to address regional imbalances. At the same time, it has proven to be a dynamic policy, responding quickly and effectively to the crisis by redirecting funds towards priority areas, as well by investments in key sectors to generate economic growth and jobs.

Having a budget of 351.8 billion euros, representing about a third of the EU budget, the Cohesion Policy represents as well for the period 2014-2020 an essential component of the Multiannual Financial Framework and it is the main investment tool for achieving the objectives of the European Union.

The absorbency degree at national level of the cohesion funds in the 2007-2013 programming period in February 2015 was $64.47 \%$, Romania being the second smallest of 
EU. Thus, for the current period Romania must make greater efforts to attract these funds in order to reduce disparities between regions.

\section{ACKNOWLEDGEMENTS}

This work was supported by a grant of the Romanian National Authority for Scientific Research and Innovation, CNCS - UEFISCDI, project number PN-II-RU-TE-2014-4-1134.

\section{REFERENCES}

CATANĂ, AIDA (coord.), (2007): Elaborarea proiectelor cu finanţare din Fondurile Structurale pentru IMM-uri 2007-2013, Publisher Contaplus, Ploieşti (Development projects financed by the Structural Funds for SMEs 2007-2013 Contaplus, Ploiesti)

FEHER, A. (2009): Finanţarea agriculturii şi dezvoltării rurale. Politici comunitare (Funding of agriculture and rural development. Community policies), Orizonturi Universitare Publishing House, Timişoara

GoŞA, V., Otiman, P.I., MAteoc-SîRb, N., Feher, A. (2014): The European Funds - a driving engine of balanced economic development or of discrepancies between the member states?, Agricultural Economics and Rural Development, Year X, No. 1, pp. 3-18

EUROPEAN COMMISSION (2010): Communication from the Commission to the European Parliament, the Council, the European Economic and Social Committee and the Committee of the Regions, "The CAP towards 2020: Meeting the food, natural resources and territorial challenges of the future", Avaible at http://ec.europa.eu/agriculture/cap-post2013/communication/com2010-672 en.pdf

MINISTRY OF EUROPEAN FundS, Partnership Agreement of Romania for the 2014-2020 programming period

OFFICIAL JOURNAL OF THE EUROPEAN UNION, L347 / 320 REGULATION (EU) NO. 1303/2013 OF THE EUROPEAN PARLIAMENT AND OF THE COUNCIL of 17 December 2013 laying down common provisions on the European Regional Development Fund, European Social Fund, Cohesion Fund, European Agricultural Fund for Rural Development and the European Maritime and Fisheries as well and laying down general provisions on the European Regional Development Fund, European Social Fund, Cohesion Fund and European Maritime and Fisheries Fund and repealing Regulation (EC) No $1083 / 2006$ of the Council 